\title{
A presença da violência na cena contemporânea Três casos argentinos
}

\author{
Halima Tahan
}

1.

Há já algum tempo que a representação da violência faz parte do nosso quotidiano; de forma rotineira os meios de comunicação de massa fazem chegar as imagens do horror ao círculo doméstico. É algo inegável - já assinalado por Susan Sontag (2004: 115-117) - que na cultura de massa (nos filmes, historietas, TV, jogos electrónicos, Internet) se regista um aumento crescente e consentido da violência e do sadismo. Há algumas décadas atrás, muitas das imagens, que os adolescentes hoje observam impávidos, teriam perturbado uma boa parte do público. Para muitas pessoas na maioria das culturas modernas, a mutilação é mais divertida do que chocante. No entanto, nem todos os sucessos violentos são vistos com tal desapego: "ironicamente alguns desastres são melhores temas do que outros".

Neste contexto, assistimos frequentemente à representação da violência em cena, com diversos graus de intensidade e de proximidade, segundo a configuração estética do espectáculo. A que se pode associar essa presença avassaladora? À busca do impacto no público e nos meios de comunicação, ou ao genuíno interesse em questionar situações humanas extremas? 0 que a torna atractiva? 0 nosso "amor pela maldade"? Ou que outras motivações podem estar por detrás disso?

Ainda que não exista um padrão determinado para responder a estas questões, não é possivel responder de forma genérica. Assim, ir para além de uma retórica reiterativa sobre estas - sem dúvida transcendentes questões, ou sobre as possibilidades de a crítica poder produzir um conhecimento esclarecedor sobre elas, exigiria a abordagem de produções concretas referindo as suas condições de emergência e a sua recepção em determinados contextos.

A cena argentina, de uma grande extensão e variedade, ostenta e ostentou casos sonantes como Passo a dois (Paso de dos) de um importante e polémico homem de teatro como Eduardo Pavlovsky; algumas produções memoráveis de El Periférico de Objetos como Maquina Hamlet, ou Monteverdi método bélico, ou a recente Sobre penitências e autópsias (De penitencias y autopsias), estreada em Córdova em finais de 2007, pelo uruguaio Sérgio Blanco, que elaborou um projecto baseado em histórias que se desenrolam no espaço da cadeia e da morgue, com dramaturgos e actores locais.
Também em 2007, Griselda Gambaro, considerada uma das mais importantes dramaturgas argentinas, escreveu A persistência (La persistencia) partindo de um episódio sangrento: o assalto a uma escola na Rússia, por um comando tchetcheno, em que morreram mais de trezentos reféns, a maioria crianças, cujas vidas o governo não quis negociar. Gambaro conta - no programa do espectáculo - que "a obra fala da persistência do ódio, da grande interrogação que nos coloca... e quando o problema usa o artifício do teatro, faz o que a realidade não consegue fazer: abdica de desculpas, faz-se corpo em cena para distinguir e confundir o horror e o humor, o que somos e qual é a nossa escolha".

Seleccionaram-se para esta reflexão: 0 matadouro 5 : Uivo (El Matadero 5: Aullido), uma perfomance dirigida por Emilio Garcia Wehbi; Manifiesto vs Manifiesto, obra de Susana Torres Molina e Purificados (Cleansed) de Sarah Kane, com direcção de Mariano Stolkiner, tomando como ponto de partida imagens das montagens escolhidas.

Nos três espectáculos (em diferentes graus e medidas). aparecem como estrutura principal o corpo, o ritmo e a palavra. Em Uivo e Purificados a violência tem como cenário os próprios corpos num espaço de clausura que adquire valor simbólico. Em Uivo são os corpos e as suas pulsões que impulsionam a performance orientando a percepção do teatral e do social. Em Kane é o corpo atravessado pela linguagem que instaura a cena; uma cena onde têm lugar práticas que subvertem toda a norma social. Enquanto que Manifiesto promove as suas experiências cénicas a partir da linguagem. Em todos estes espectáculos, de maneiras diferentes, é certo, pode estabelecer-se uma relação homóloga entre corpo cénico e corpo social.

\section{O matadouro 5: Uivo: 0 sangue dos outros} A série 0 matadouro', que Emílio García Wehbi - encenador, cenógrafo, co-fundador do reconhecido grupo El Periférico de Objetos - realizou a partir de 2005, inscreve-se numa linha de espectáculos provocadores que procuram desestabilizar o espectador. Esta série, que tem como referência (ainda que não central) um clássico da literatura argentina, 0 matadouro de Esteban Echeverría, também mergulhou nas experiências da anti-psiquiatria e procurou delinear, ao longo das suas pesquisas, "uma poética da enfermidade" como fica bem demonstrado no caso de Uivo.
As edições anteriores foram El Matadero: Slaughterhouse (2005), El Matadero. 2 (2006), El Matadero.3 (2006) e EI Matadero.4: Respondez! (2007). Em Abril de 2008, realizou-se em Ciudad Juárez (México) o sexto episódio, baseado nos assassinatos de mulheres que ocorreram nessa cidade.

Halima Tahan é Professora na Universidade Nacional de Córboda, Argentina, dramaturga e critica de teatro. É directora das Ediciones Artes del Sul e da revista Teatro al Sur: Revista latinoamericana (Córdova, Argentina). 
O matadouro 5: Uivo,

a partir de Howl,

de Allen Ginsberg et al.,

dir. Emilio Garcia Wehbi,

Ciudad Cultural lones,

Buenos Aires, Argentina,

2008

[cortesia de autora].

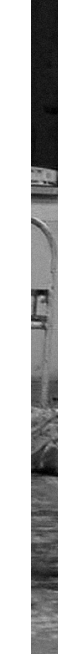

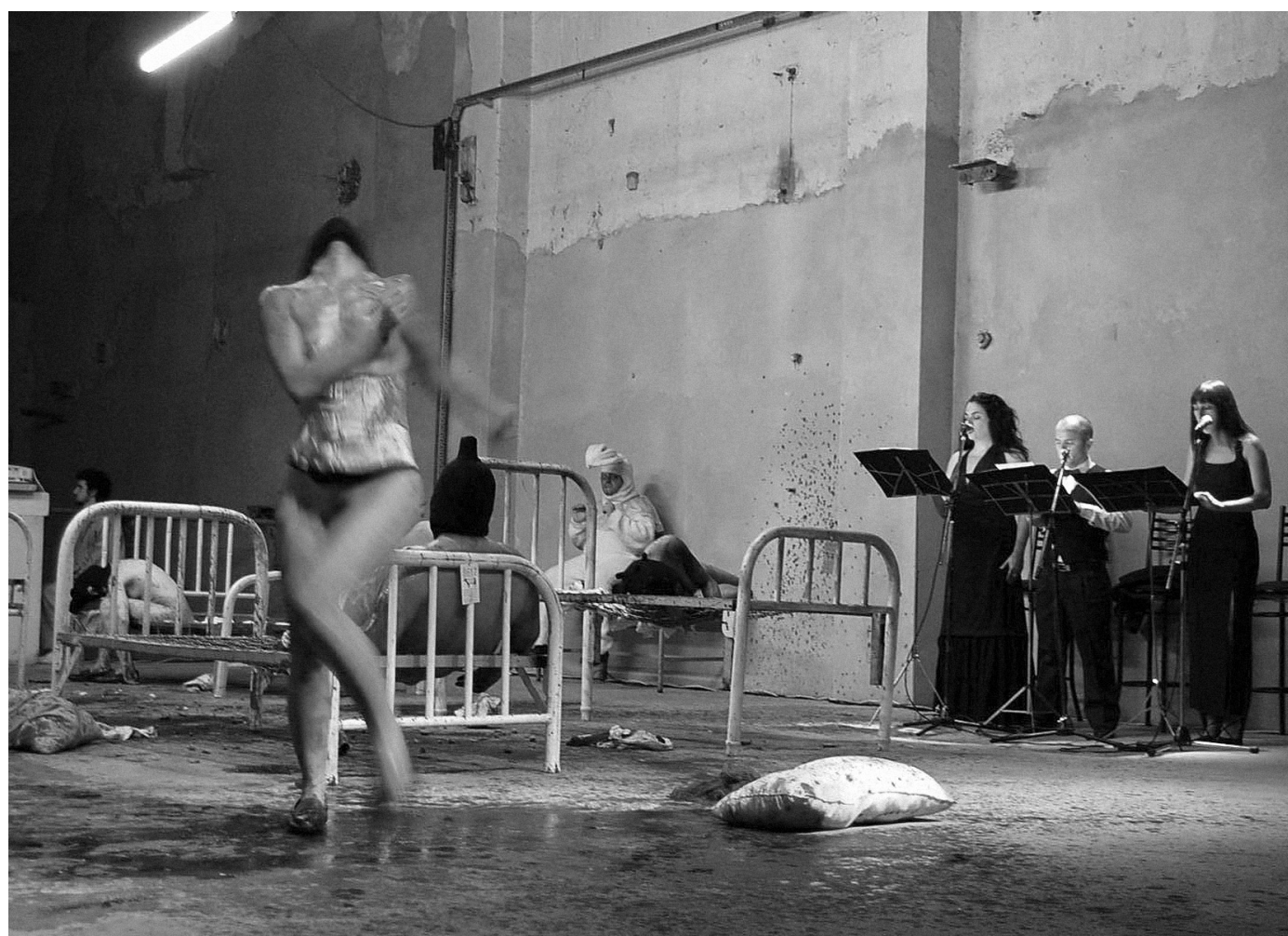

A quinta produção desta série baseia-se no poema Uivo (Howl) de Allen Ginsberg, texto emblemático da geração beatnik. García Wehbi articulou esta nova proposta apoiando-se, por um lado, na concepção artaudiana do teatro total e, por outro, no conceito de performance. Uivo consistiu na leitura completa do texto de Ginsberg ${ }^{2}$, apresentado como uma espécie de diálogo entre o poema e as situações que se sucediam no espaço. 0 polémico espectáculo, que teve tantos detractores como defensores (e nisso radica também o seu interesse) desenrolou-se num grande espaço fechado, a que se acedia por uma escada. Uma vez ali, os espectadores permaneciam de pé, diante de um espaço onde se iniciava a performance; atrás, antigas camas de hospital; à direita, o local de onde os actores recitariam com uma eloquente intensidade 0 poema de Ginsberg; num plano de fundo, a projecção de imagens ${ }^{3}$ prolongava o espaço e multiplicava-o virtualmente.

Desde o início, o espectáculo girava em torno do vértice do abjecto. A abertura, de carácter ritual, culminou num episódio em que se tirava sangue aos actores: sangue que foi posteriormente misturado e bebido por uma performer. É no acto da re-ingestão desse fluxo corporal nobre - como é considerado o sangue - que se adquire uma significação mais corrosiva e violenta. A sequência articulada pela acção de extrair sangue põe em evidência a fragilidade das

A que se juntaram outros textos de Antonin fronteiras corporais. 0 vulnerável limite do corpo, com a identidade que resguarda, é agredido e saqueado, neste caso, perfurado. Em cena desenrola-se o confronto entre "a necessidade de controlo social e a força da pulsão" (Frappier-Mazur 2006: 10); termos que, não sem violência, o ritual procura veicular simbolicamente. A violência pulsional que, nesse espaço de clausura, "os pacientes" geram, opõe-se à violência supostamente "racional", não menos excitante e visceral, através da qual se reafirma a hierarquia do poder. Uivo procura "performatizar" os vínculos do pulsional com o político e o social.
Os corpos actuantes vestidos de branco manchamse com o sangue; a ostentação do sangue em cena acentua o seu protagonismo simbólico bem como o da "mancha", sindrome de impureza, que denuncia a perigosidade dos seus portadores. Poder-se-ia convocar aqui, ainda que num outro sentido, a afirmação de Foucault: "0 poder fala através do sangue" (apud ibidem: 134).

Convém retomar aqui a ideia do contraponto entre a leitura do poema e as situações cénicas; que, em termos gerais, respondem ao princípio da repetição, remetem para a figura subjacente de o Mesmo. A experiência da desordem suscitada pela obra, impelida pelos "símbolos de impureza e de perigo" (Ibidem: 10-11) que nela se exibem, conduz ao hibrido que tem como qualidades a mistura e o excesso (Douglas 2007).

$\mathrm{Na}$ cena, que os performers promovem e mobilizam através das suas acções, dá-se um domínio do gesto sobre a palavra, sobre a acção de nomear; no entanto, quando essa espécie de "maquinaria de assalto à tradição" que é o texto de Ginsberg, explode no espaço através do corpo e da voz dos actores que desfiam o poema, a performance muda de dimensão: os corpos actuantes e a sua redução sobre a cena são percebidos de outra maneira.

As imagens visuais que se projectam no fórum também se impregnam do texto; a palavra proferida - uivada conjura a "vertigem do abjecto" que a cena gera, nega-o simbolicamente, e é por esse conjuro, resultado da colisão da palavra poética com o espaço e com os corpos, que a obra não sucumbe às metáforas da regressão, da retirada. Pelo contrário, intensifica a dialéctica entre o interior e o exterior, conjurando assim o enclausuramento, interpelando o mundo.

\section{Purificados: Eros mutilado}

No Teatro Ferroviário, localizado em antigos armazéns da principal estação de comboios de Buenos Aires, sob a 

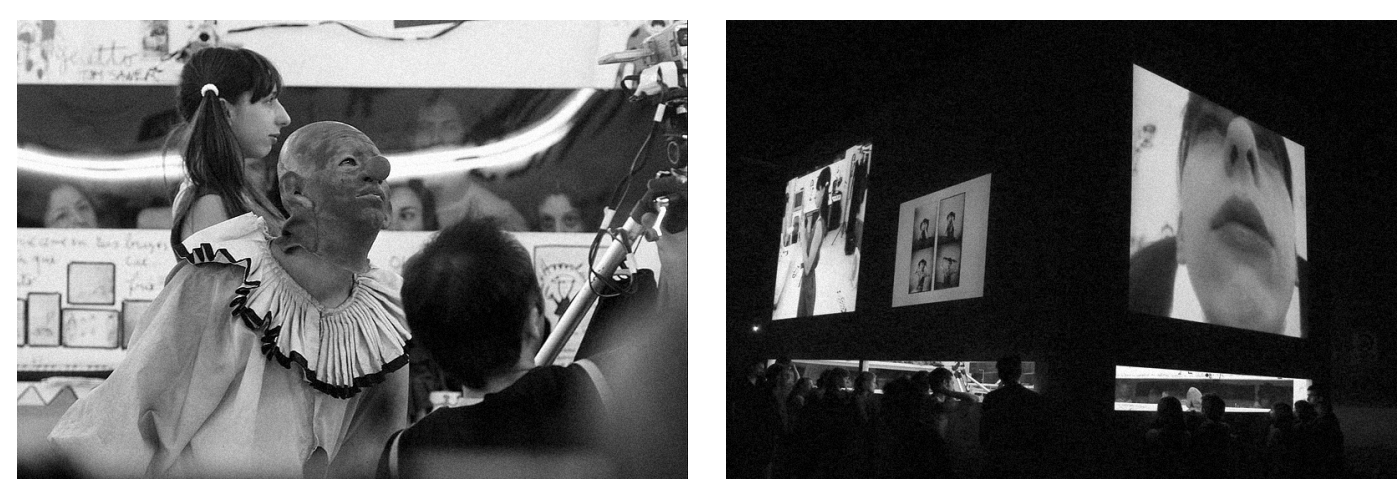

$<>$

O matadouro 5: Uivo

a partir de Howl

de Allen Ginsberg et al., dir. Emilio Garcia Wehbi, Ciudad Cultural Iones, Buenos Aires, Argentina, 2008 [cortesia de autora].

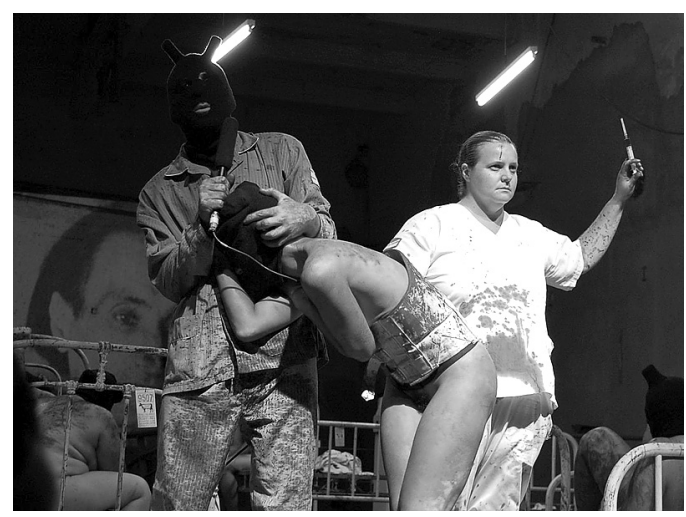

direcção de Mariano Stolkiner, foi apresentado Purificados, a estimulante obra de Sarah Kane. Os espectadores são conduzidos, num autocarro fechado, até à sala que se encontra praticamente às escuras, conferindo um ar clandestino a todo este procedimento. Esta obra, bastante divulgada, impõe como poucas, aos actores e espectadores, uma violência física sem precedentes.

As acções de Purificados desenrolam-se, significativa e paradoxalmente, numa universidade: no ginásio, no sanatório, na biblioteca; são espaços multifacetados que vão sugerindo outras identidades: sala de torturas, laboratório sinistro, campo de concentração, incluindo a apresentação até um peep-show. Porém, o verdadeiro palco da violência é o dos corpos brutalmente agredidos, desmoronados, saqueados...

A sexualidade, aqui indissociável da violência, manifesta-se na condição estética e ideológica da encenação. Uma sexualidade cuja representação, por certo, engloba também a representação do social. Estamos na presença de um teatro da crueldade que, ao contrário do que postulava Artaud, a mostra em cena, fazendo dela a sua matéria física e dramática. A obra propõe um ritual cruel impulsionado, em parte, pelos fantasmas violentos que perseguem Kane; uma ritualidade já sugerida no próprio título.

Purificados admite diversas leituras. Purificar implica "retirar de uma 'coisa' o que Ihe é 'estranho'". Operação que requer um protocolo, um ritual. 0 significado da purificação está saturado de antigas conotações litúrgicas, cerimoniais, sacrificiais, mas tem também conotações contemporâneas, laicas e políticas.

Respondendo à lógica transgressora do texto, na obra invertem-se as habituais relações semânticas que se atribuem à purificação. Sustenta Mary Douglas que "uma estrutura social que se apoia num elevado grau de controlo consciente encontrará o seu estilo num elevado nível de formalidade, numa estrita aplicação da regra de pureza" (Douglas 2007); é 'essa regra' que Kane inverte e desafia; que tenta quebrar, para que pelas suas fendas surjam "os terriveis abismos subterrâneos do ser" (Rüdiger 2002: 69). Kane tenta descidas dramáticas ao "abismo aberto em nós pelo erotismo e pela morte" (Ibidem: 191).

Em Sarah Kane - como em Nietzsche - o sentimento do estilo manifesta-se através de uma sensibilidade fisica, quase corporal. A força transformadora de uma obra assim, orientada para o âmbito do corpo, só pode ser forjada "se se revestir de um corpo linguístico de grande beleza e densidade" (Bataille 2006: 76). Na busca dessa força, Kane foi intensificando nas obras posteriores a sua busca poética plasmada num "teatro do eu". Esta proposta exige uma maneira diferente de actuar e de comunicar com o espectador, dirigindo-se da própria subjectividade à do outro.

Há um tema que inquietava muito Kane: a inadequação da linguagem para expressar as emoções. Não renuncia a ela, explora as relações entre teatro e poesia buscando novas opções e novas possibilidades expressivas para essa sensibilidade física, quase corporal, que reclama - como se dizia anteriormente - "um corpo linguístico" intenso e belo. É esta relação completa entre corpo e linguagem, entre texto e cena, com as consequências dramáticas estéticas e ideológicas que comporta - a que talvez não esteja completamente dirimida na encenação de Stolkiner, que se focaliza na forte dimensão corporal da cena e no interessante dispositivo cénico que exibe desde o início.

\section{Manifesto vs Manifesto: 0 corpo como matéria dramática}

No título encontram-se já marcados dois aspectos decisivos da obra: a sobreposição e a confrontação. 0 corpo é o objecto de exploração dramática da peça, ele "é a intenção, o processo e o resultado" (Molina 2007: 3) deste empreendimento dramático escrito e co-dirigido por Susana Torres Molina.

Desde o início do texto joga-se com imagens paradigmáticas que evocam a violência: "Corpo: do latim corpus. Qualquer porção de matéria. Ex.: vejo um corpo a flutuar no rio"(Ibidem). É uma imagem que pode sugerir múltiplas associações, mas que na Argentina tem conotações sinistras: os corpos dos presos políticos que, durante a ditadura, eram atirados dos aviões para o rio. No entanto, não há uma experiência directa da violência que circula fundamentalmente através da palavra dramática.

0 Manifesto de Torres Molina teve origem na experiência exacerbada do activista vienense Rudolf 


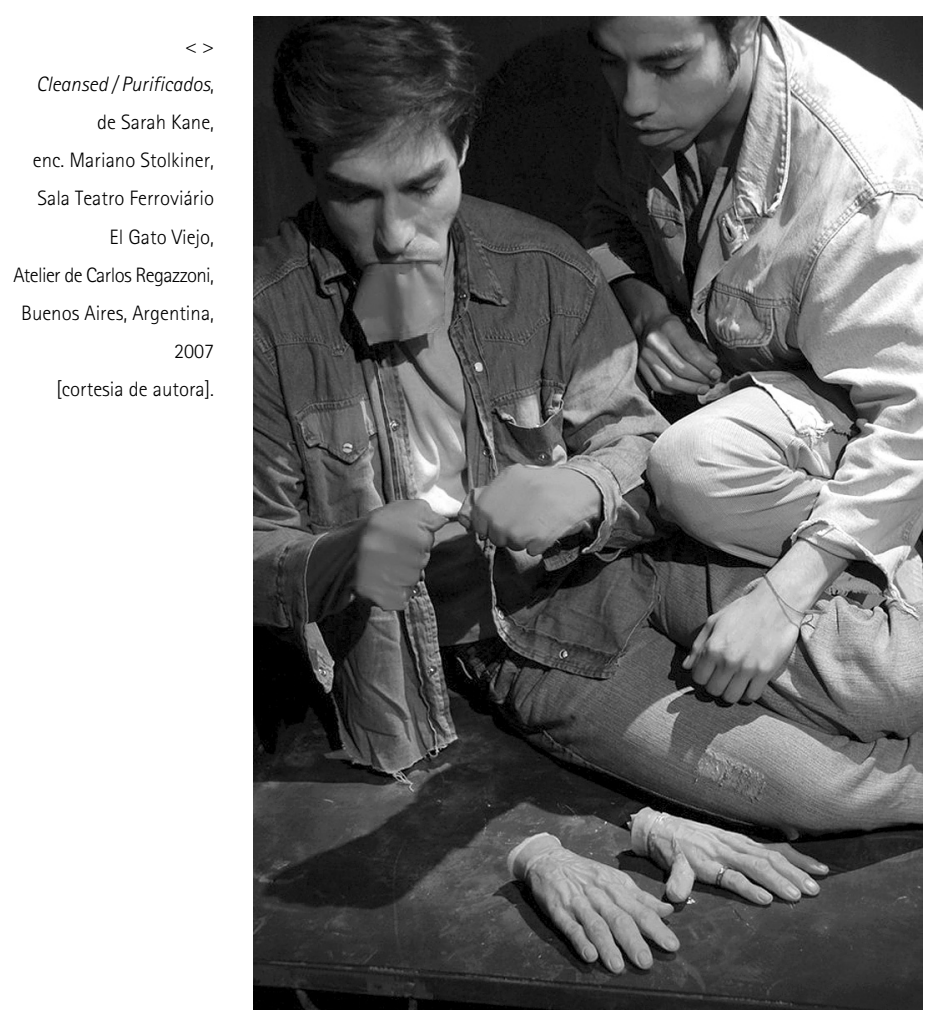

Schwarzkogler, autor de uma arte extrema que procurava "saltar no vazio e experimentar o seu corpo como ritual". A poética limite do artista vienense confronta-se com as manifestações dos três actores que participam neste projecto e que em cena contam com as suas próprias experiências pessoais, colocam questões que giram em torno da arte, da existência e dos seus corpos "domesticados".

Quer dizer que no espectáculo se misturam e convivem diferentes registos: reflexivo, narrativo, poético, dramático. Através do vídeo inseriram-se quer acções que foram especificamente criadas para este espectáculo, quer

${ }^{4}$ Escreve-se no caderno de apresentação da obra.

${ }^{5}$ Faz-se referência principalmente, a Ganther Bruss, a Otto Muhl, a Hermann Nitsch e ao já

mencionado Rudol

Schwarzkogler, que

acabou por se suicidar.

Durante o espectáculo

personagem do

Apresentador vai

mencionando estes

artistas, representados nos videos, ao mesmo tempo que declara: "A linha que apresentou o

maior grau de

transgressão e violência destes movimentos (body art) foi o activismo material dos activistas vienenses. Está-se em presença de uma forma teatral complexa que multiplica as suas perspectivas sobre o objecto corpo que as convoca: "corpo a partir do corpo dos actores" e os modos como este é percebido através da palavra e da imagem.

Os actores "expõem - a partir de um espaço íntimo, confessional - as suas descobertas sobre esse corpo que se Ihes revela alheio, assombroso e inquietante". ${ }^{4}$ Um corpo, pois, vinculado a uma poética do intimo, em convergência com uma tendência que teve (e ainda tem), para o bem e para o mal, fortes ressonâncias na arte e na literatura. As histórias que os actores trazem à cena singularizam um modo subjectivo de entender a existência; as mitologias pessoais em que se apoiam estes microrelatos aparecem distanciadas, falam do próximo e do próprio sem afectação, mesmo quando se trata de experiências muito fortes como o relato em que uma das personagens conta a violação de uma mulher, cometida por um grupo de jovens quando faziam uma despedida de solteiro. A palavra do actor traz à cena um corpo indefeso, passivo, abusado e depois abandonado.

Os corpos intimistas postos em cena entram em confronto com os "corpos de resistência" fortemente transgressores que circulam na obra através da invocação

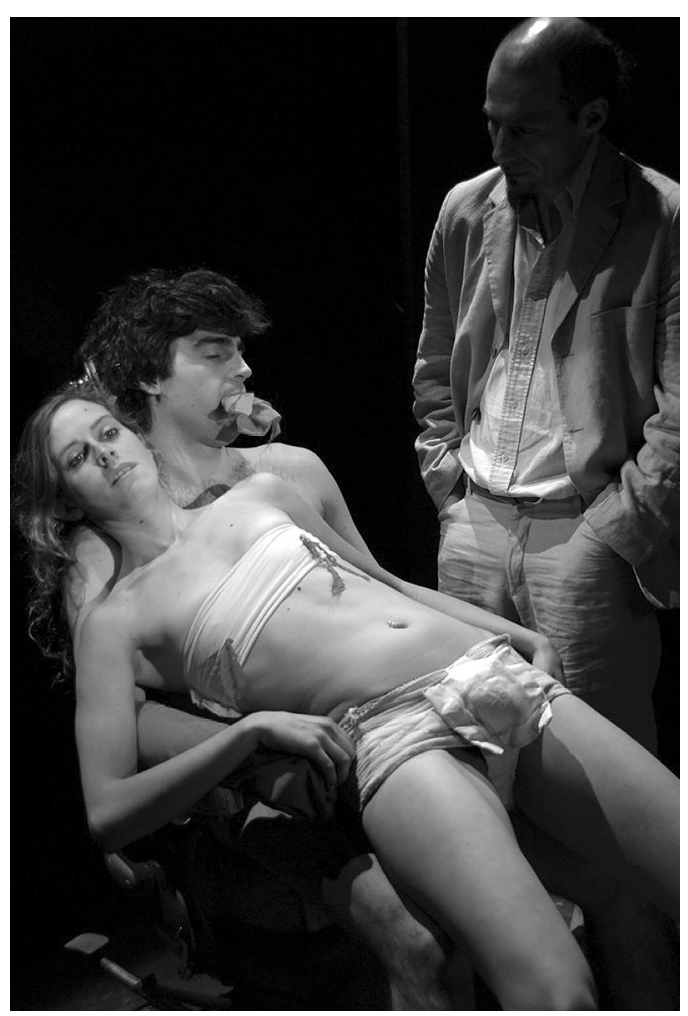

de Rudolf, o activista vienense. É essa confrontação, com a multiplicidade de aproximações ao corpo que a obra ensaia, a principal geradora de uma força activa que impede que os relatos fiquem ancorados à metáfora regressiva da retirada tanto do político como do estético, do ideológico e do social.

A experiência de violência que os activistas vienenses desenvolveram em relação ao corpo e que funciona explicitamente como ponto de partida na obra de Susana Torres circula continuamente no espectáculo através do vídeo, através de uma personagem inscrita na obra - que se desdobra na pessoa de Rudolf Schwarzkogler -, e também no relato do apresentador que explica como estes artistas ${ }^{5}$ utilizavam os seus próprios corpos e os seus fluidos (urina, sangue, excremento, sémen, escarros) como suporte para as suas acções, e que "mediante condutas violentas buscavam a revolução dos sentidos no espaço público, através da conduta animal e da dor" (/bidem: 4). Por sua vez, estas referências - entre outras - dão azo a questões específicas acerca da natureza da arte, suas condições e limites.

\section{Arte ou delito?}

As interrogações acerca dos limites da arte que os actores de Manifesto colocavam a partir do palco costumam não só alimentar obras artísticas - como ocorre neste caso e em muitissimos outros -, como, por vezes, projectar-se também muito para além do mundo da arte e da crítica: assim parece demonstrá-lo o caso do artista costa-riquenho Guillermo Vargas.

No ano de 2008 reuniram-se um milhão de assinaturas para impedir que Vargas, qualificado como artista cruel, participasse na próxima Bienal Centro Americana da Arte de Tegucilpa. A forte polémica em torno dos limites da arte e do delito foi suscitada pela "obra" que este artista apresentou, o ano passado, numa 

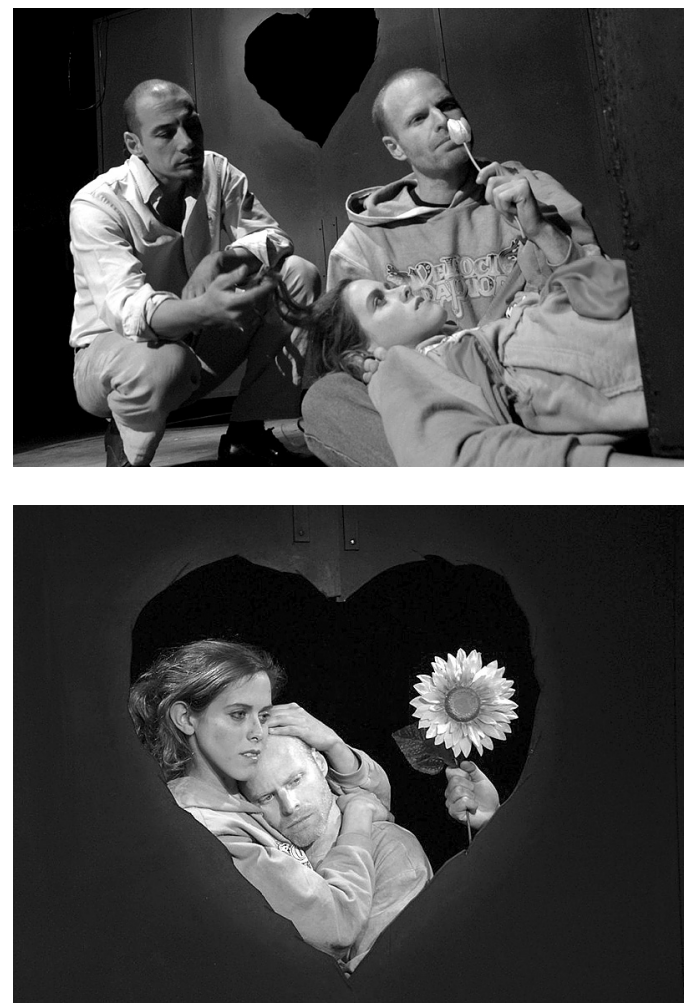

galeria das Honduras: um cão esfomeado e enfermo, preso a uma parede. Vargas deu o nome de Natividad a este animal em "homenagem" a um homem que foi devorado por um cão.

Um dos promotores desta campanha - atrás da qual se encontra também a Sociedade Mundial para a Protecção dos Animais - é o proteccionista espanhol Jaime Sancho, que afirma: "o juizo moral sobre este senhor já está ditado, o mundo inteiro sabe que Guillermo Vargas é um torturador de animais e que em 'nome da arte' a sociedade internacional não admite tudo".

Pelo seu lado, Vargas considera que, se a sociedade "não admite tudo" no terreno da arte, o mesmo não se passa no da realidade. Em declarações à imprensa Vargas disse: "o importante é a hipocrisia das pessoas: um animal assim converte-se em foco de atenção quando o coloco num local onde as pessoas vão ver arte, mas não quando está na rua morto de fome. Passou-se o mesmo com Natividad Canda: ninguém se sensibilizou com ele até os cães o comerem. Ninguém libertou o cão nem the deu comida ou chamou a polícia. Ninguém fez nada".

\section{Dizer não}

Há toda uma produção artística, muito dispar em termos estéticos e ideológicos, em que a violência tem presença decisiva e que parece responder tanto ao clima cultural e político dominantes como às tendências que marcam a cultura de massas. Uma cultura em que - como se assinalava anteriormente - se constata permanentemente um crescente aumento do sadismo e da violência. As imagens violentas são parte quase normal de uma cultura em que "a comoção se converteu na principal fonte de valor e estímulo do consumo" (Sontag 2004: 32), uma estratégia decisiva na hora de chamar a atenção sobre a própria produção artística que deve desafiar o contínuo fluxo de imagens a que nos encontramos sobreexpostos.
Abundam relatos que apresentam, sem descriminar, acções violentas de forma muito crua e "de canibalismo urbano sem nenhum horizonte de ideias, inclusivamente com uma recusa sacrificial em relação a qualquer ideia geral" (Trias e Argullol 1992: 12); para o filósofo espanhol Eugénio Trías, estas obras permitir-nos-iam compreender, pela negativa, o horizonte da época, mas o mais apelativo e o mais atemorizante talvez se encontre nessa recusa que qualifica como "sacrificial", e que, na sua perspectiva, poderia conduzir a um "totalitarismo sem ideias" (Ibidem) incentivado pelo ressurgimento do medo na fortaleza do Ocidente.

Como reagir criticamente a esta produção? Talvez seja um bom exercicio "resistir à atmosfera da época", como sugeria Albert Camus; dizer não, em primeiro lugar a si próprio como crítico, no sentido de não se vergar às correntes em voga, arcando com o custo que isso possa acarretar; não porque se seja dono da verdade no que respeita à redenção das relações complexas entre estética e violência, ou à determinação do grau de horror ou de crueldade admissivel em cena. Talvez não tenhamos a resposta certa, nem saibamos "a verdade" a respeito destes temas, mas sabemos bem o que é mentira e resta-nos, pelo menos, a possibilidade de dizer, com Camus, que "não mentimos".

\section{Experimentação de hominis natura}

É certo que a violência se transforma, como se transformam também as suas formas de representação. Ao longo dos séculos os cenários das guerras foram mudando à medida que mudavam os armamentos. Actualmente fazem-se experiências com as armas farmacológicas - ligadas aos avanços das ciências médicas. São estudos que operam na fronteira da legalidade e constituem "uma séria ameaça para a humanidade", como afirma Vivien Nathanson, da Comissão de Ciência e Ética da Associação Médica Britânica.

Há amargos exemplos do uso de drogas como armamento (no Vietname, na Irlanda do Norte), mas o caso que desencadeou um gigantesco alarme foi o trágico acontecimento que teve lugar em Moscovo durante 0 assalto ao Teatro Dubrovka, no ano de 2002, onde se propagou pelo sistema de ventilação um derivado da droga fentanyl, mais forte do que a morfina. Espera-se, e não sem pânico, que estas armas mudem o cenário das guerras: agora será o corpo o campo de batalha e "a orgia da irracionalidade" - no dizer de Benedetto Croce consumar-se-á nele. Práticas inumanas? É válida essa qualificação ou terá já perdido todo o significado?

Nestas circunstâncias, como distinguir o humano do inumano? Qual a moldura crítica que o produz? 0 que 


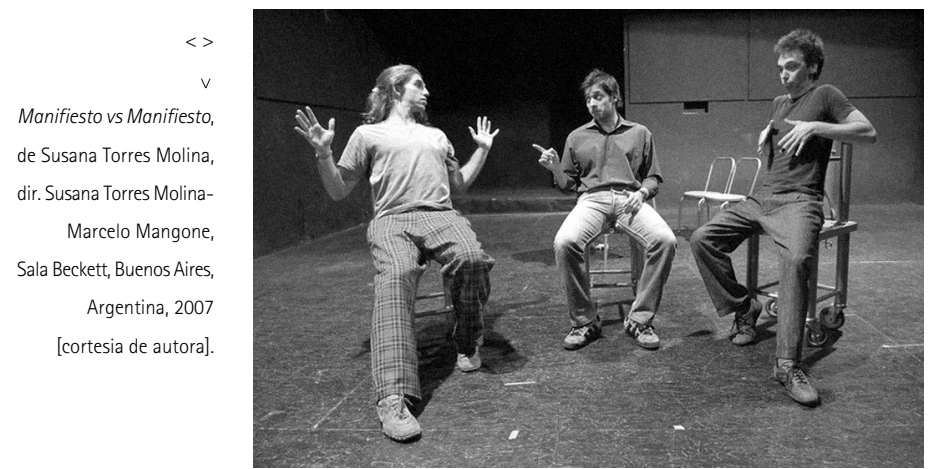

distingue e, ao mesmo tempo, o que aproxima o humano do animal? Essa diferença - essencial para a nossa cultura - ameaça apagar-se, e quais seriam as suas implicações? Giorgio Agamben sustenta que o que está "em jogo nesta diferença é a experimentação cognitiva que, em última análise, diz respeito à natureza do homem. (...) Quando a diferença desaparece e os dois termos chocam um contra o outro - como parece acontecer hoje - também a diferença entre o ser e o nada, o lícito e o ilícito, o divino e o demoníaco, diminui, e em seu lugar aparece qualquer coisa para a qual até os nomes parecem faltar-nos. Talvez também os campos de concentração e de extermínio sejam uma experiência deste género, uma tentativa extrema e monstruosa de decidir entre o humano e o inumano que acabou por envolver na sua ruína a própria possibilidade de distinção" (Agamben 2006: 49).

\section{As reiterações significativas da arte}

Figurar tanto o sofrimento como a guerra e a morte tem sido um objectivo permanente não só da arte contemporânea, mas da de todos os tempos. A razão da persistência deste objectivo desafiador na arte tem merecido diversas respostas. Umberto Eco, no seu livro História do feio, pergunta-se "E se os cyborg, splatter e mortos vivos forem simples manifestações superficiais, enfatizadas pelos meios de comunicação, mediante as quais exorcizamos uma fealdade muito mais profunda que nos assedia, nos aterroriza e gostariamos de ignorar?"(Eco 2007: 431-437). No dia-a-dia, afirma o autor, estamos rodeados de espectáculos horriveis, de acontecimentos violentos e lacerantes: imagens de crianças mortas de fome, de países onde os invasores violam as mulheres e de outros onde se torturam seres humanos. São-nos apresentadas imagens "de esqueletos vivos a entrar na câmara de gás", vemos imagens de membros destroçados pelo estoiro de edifícios ou aviões; todos sabemos que estas coisas são feias, não só do ponto de vista moral, mas também físico, "porque provocam desagrado, medo, repulsa, para além de outros sentimentos como revolta, solidariedade, piedade ou desprezo [e] nenhuma consciência da relatividade estética" (Ibidem) pode impedir que sejam reconhecidos como feios e que seja impossivel transformá-los em objectos de prazer.

Compreendemos então porque é que, ao longo das diversas épocas, a arte reitera repetidamente a representação do feio e que, embora a sua voz seja marginal, quer recordar-nos que "apesar do optimismo de alguns metafísicos, neste mundo há algo irredutivel e tristemente maligno" (Ibidem), conclui Eco, convidando a entender a deformidade como drama humano.
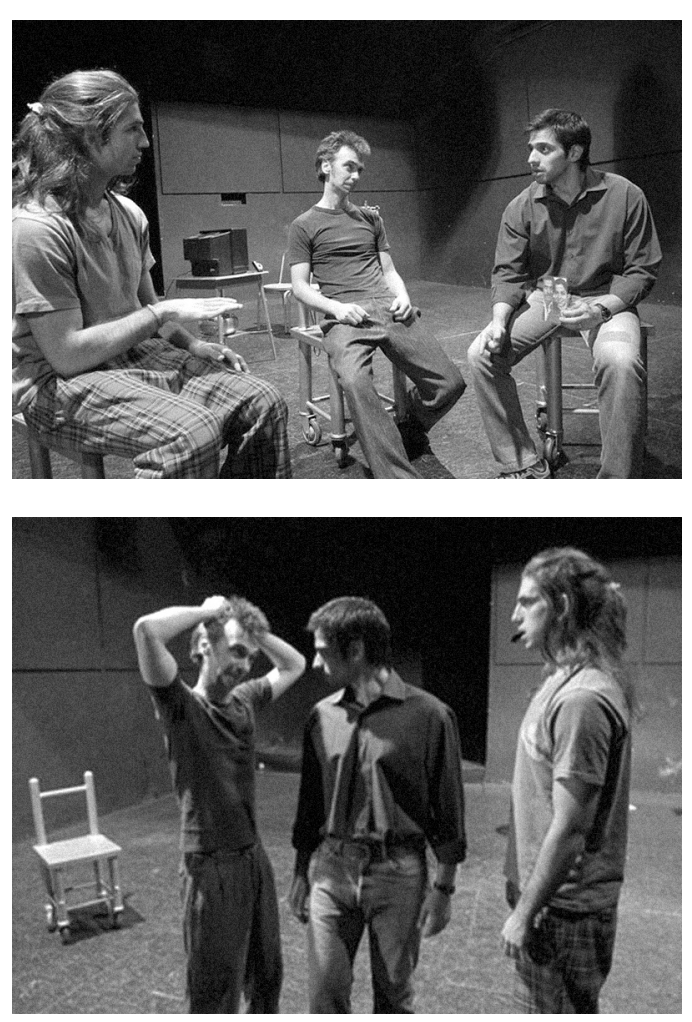

Muitas obras de arte, para além de recordarem o carácter "irredutivel e tristemente maligno" deste mundo, como assinala Eco, funcionam como "verdadeiras máquinas de pensar" - sobretudo no terreno do documentário capazes de libertar a palavra e de fazê-la circular, pô-la em jogo, para trazer à superficie as disfunções de uma sociedade enferma, despertar as consciências e construir testemunhos. Construir, quem sabe, nesses momentos de graça, o "ser com".

É possivel, no entanto, inventar territórios que se possam partilhar? Talvez devesse dizer como Ernst Bloch que professo um "optimismo de luto", que me permite combinar a esperança com o cepticismo, uma esperança paradoxal que alimenta as minhas apostas na labuta diária do teatro e da vida.

\section{Referências bibliográficas}

AGAMBEN, Giorgio (2006), Lo abierto, Buenos Aires, Adriana Hidalgo Editora. BATAILLE, Georges (2006), Les /armes d'Éros, Paris, Éditions 10/18. DOUGLAS, Mary (2007), Pureza y peligro: Un análisis de los conceptos de contaminación y tabú, Buenos Aires, Nueva Visión.

ECO, Umberto (2007), Historia de la fealdad, Buenos Aires, Ed. Lúmen.

FRAPPIER-MAZUR, Luciente (2006), Sade y la escritura de la orgía, Buenos

Aires, Ed. Artes del Sur.

MOLINA, Susana Torres (2007), Manifiesto vs Manifiesto, original inédito cedido pela autora.

RÜDIGER, Safranski (2002), Nietzsche: Biografía de un pensamiento, Barcelona, Tusquets.

SONTAG, Susan (2004), Ante el dolor de los demás, Buenos Aires, Alfaguara TRIAS, Eugénio e ARGULLOL, Rafael (1992), "Ideas para mirar el mundo: Diálogo entre Eugénio Trias y Rafael Argullol", Suplemento Futuro, Março, p. 12.

Tradução de Andreia Azevedo 